\title{
Nature's Schoolhouse
}

Boys and girls will still have one more opportunity to win a valuable nature field guide, by submitting an essay for the next issue. All entries which have been or will be printed in THE BLUE JAY, are also eligible for the grand prize, the $\$ 50$ camera, donated by Bird Films. This prize will be awarded in June or July.

Here are the rules of the contest. Write an original story of one of your nature observations. Confine it to less than 500 words. Send your name, address, age, grade and school to the editor, L. T.
Carmichael, 1077 Garne for the reception of $\mathrm{m}$ will be April 15, 1955.

A choice of Peterson's mals or butterflies) o plus a subscription to given as a prize for $t$ the next issue. At their award several addition: your story please indica

PRIZE WINNERS:

\section{The Flight Song of the Prairie Horned Lark}

\author{
By LAVERNE WENDELL, MacNutt, Sask. \\ Age 14, Grade 9
}

Drawing by Robert Seibert (Audubon Magazine)

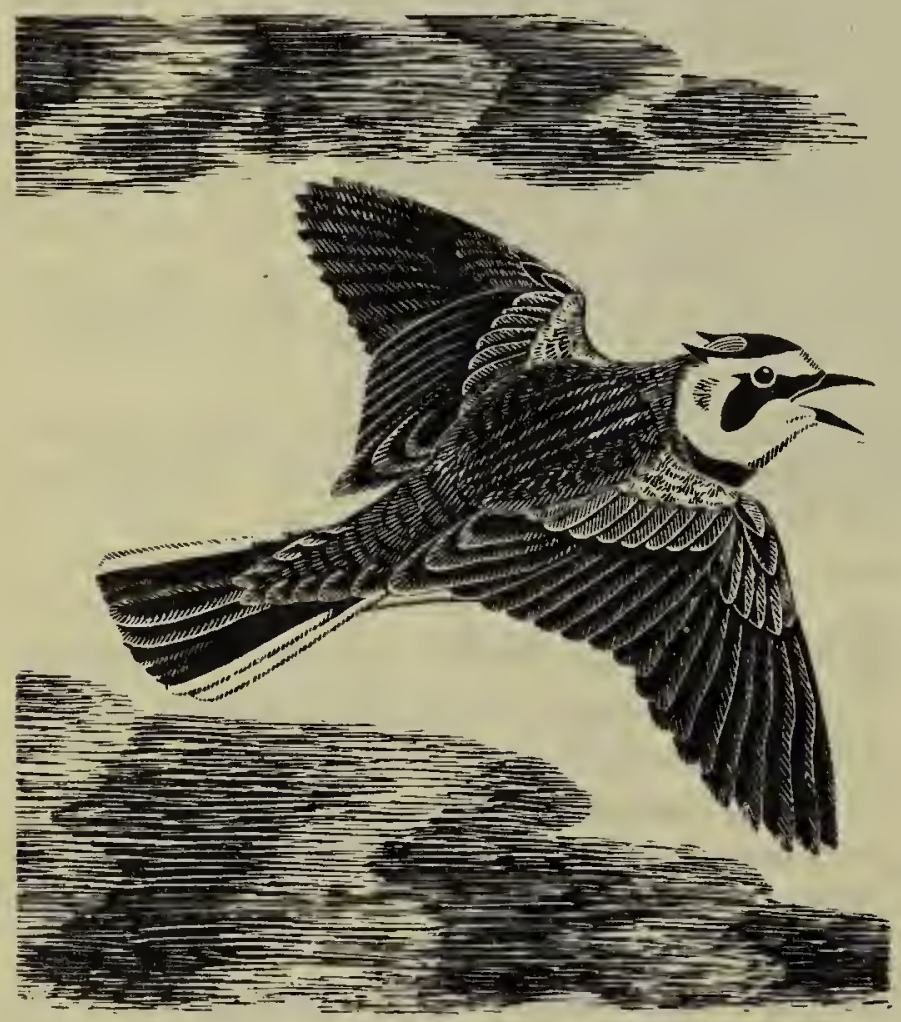

Hail to thee, blithe Spirit! Bird thou never wert,

That from Heaven, or near it, Pourest thy full heart

In profuse strains of unpremeditated art.

One afternoon, late in June, while. driving along a country road, Dad suddenly stopped the truck and told me to watch a Horned Lark which was rising by the side of the road. It rapidly gained elevation through consecutive spurts and glides till it had reached a height of what seemed to be about two hundred feet. I thought it would fly away, but Dad who had witnessed this performance before, assured me that it would circle and told me to listen closely when it spread its wings.

At first I couldn't hear anything but after a while I distinctly heard the song of the Horned Lark that one so commonly hears with its return in the spring of the year. This performance continued for about five or ten minutes after which it unexpectedly folded its wings and, in dive bomber fashion, dropped straight down giving the impression that it must crash headfirst into the ground. With less than ten feet from the ground, and while I was holding my breath for the crash, its wings suddenly opened and gliding a few short feet away it sat down as though it hadn't performed at all. This performance is rarely seen. It was the first time I had ever witnessed the strange flight and common song of the Horned Lark way up in the sky. Dad told me he had the pleasure of seeing and hearing it on two or three other occasions many years ago.

As we drove home I felt considerably thrilled that I had witnessed this rare flight song of the Horned Lark. I hoped that in the not too distant future I might again have the opportunity of being audience to the Horned Lark's performance. 